\title{
研究会インタビュー ソサイエティ人図鑑 No.30
}

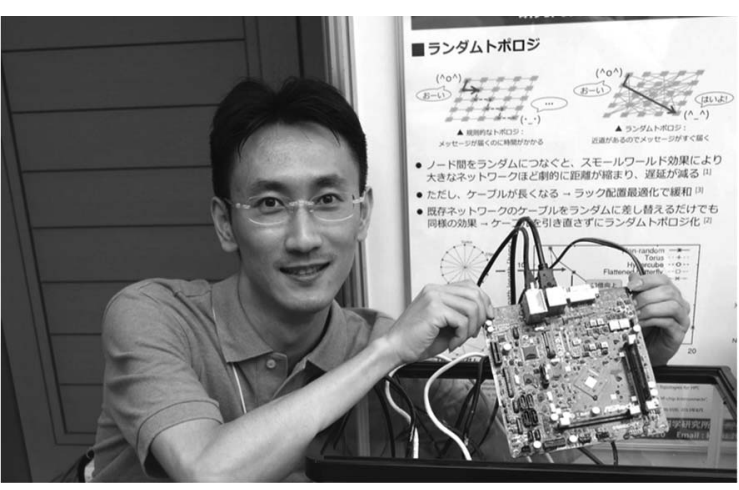

藤原一毅さん

所属：国立情報学研究所オープンサイエンス基盤研究 センター特任准教授

分野：オープンサイエンス，クラウドコンピューティング, 最適化

インタビュー：西尾直樹（聴き綴り本舗 nishio.naoki@gmail.com）, 編集：佃芳史春

\section{— 研究についてお聞かせ下さい.}

公開されている研究データを活用して新たな 研究を簡単に始められるオープンサイエンスの 基盤を研究しています。具体的には，データ公開 インフラと計算コンピューティングインフラと の繋ぎの部分で，ある研究者が作った計算基盤 のセッティングを別の研究者が簡単に再利用で きるようなシステムの構築です，昨年から試験 運用を始め, 現在は数值データの統計分析に限 定して使われていますが，今後はスーパーコン ピュータが使われるような複雑な計算にも適用 できる仕組みに育てていきたいです。データの 性質と処理内容を勘案して最適な計算機を提案 できると良いと思っています。一口に研究デー 夕といっても，ゲノムデー夕, 地球観測デー夕, アンケート, 古文書など様々. 分野によって属性 の異なる多くのステークホルダーがいます，ど うすれば皆が進んでデー夕を公開するか. その インセンティブを設計するのも重要な仕事です. 研究データの公開・再利用を通じてオープンサ イエンスの世界が実現するには，デー夕基盤の 開発を専門とする技術者をはじめ，デー夕を作
成・収集する生産者や，多種多様なデー夕を整理 するキュレーターなど，幅広い人材の活躍が必 要です。論文の著者にならないこれらの人々は 従来, 学術的評価の対象になっていませんでし た。ですが，近年になってデー夕流通に携わる 人々を研究者の一員として正当に評価し，学術 に貢献するインセンティブを与えるべきだとい う認識が広まりつつあります。私自身，リサー チャーというよりエンジニアに近い性格の持ち 主で，ユーザが直接触るシステムを作って実際 に使ってもらうことにやりがいや面白みを感じ ています。私のような人材を学術機関が安心し て雇えるように 笑), 論文数だけでない新たな 評価軸を作る活動にも取り組んでいきたいです。

\section{一 今に至る経緯についてお聞かせ下さい.}

根っこは鉄道ファンです. 父親が乳児の私を肩 掛け鞄に入れ, 東武線竹ノ塚駅の踏切脇で日が な一日列車を眺めていたのが始まりでした、鉄 道ファンといっても乗り鉄, 撮り鉄, 模型鉄, 切 符鉄，信号鉄，弁当鉄などいろいろですが，私 は主にダイヤ鉄です。学生の頃「ぼくのかん がえたさいきょうの京葉線ダイヤ」を画用紙に 
描いたりしました. 中学生のとき, 枕崎から稚 内まで夜行列車で 7 日かけて日本縦断したのは 良い思い出です。

大学では東工大制御システム工学科に進み, 国 際ロボコンにも出場したのですが, 周波数領域 で物事を捉える世界に馴染めずドロップアウト. 4 年生時に，当時グリッドコンピューティングを 研究していた合田憲人先生に出会い, if-then-else の世界で生きる覚悟を決めました。就職活動で は，列車ダイヤを司る「スジ屋」と呼ばれる職 業にあこがれて鉄道会社を何社か受けたのです が，残念ながら不合格.ならばスジ屋が使うシ ステムを作ってやろうじゃないかと, 日立製作 所に入社しました。

配属された茨城県の大みか工場で, JR 在来 線の運行管理システムを担当しました. 鉄道会 社の指令室で, 大きなディスプレイの前に指令 員さんが座って信号やポイントを操作している, あのシステムです，指令室では日夜，スジ屋が 列車遅延と戦っています。乗客の立場から見る と,「○○線はいつもダイヤが乱れていてけしか らん!」と思うかもしれませんが，指令室から見 ると, スジ屋とシステムが人馬一体となって常 に最善の手を打っていることが分かります. ダ イヤ鉄としては非常に楽しい仕事でした。

列車ダイヤの目的は，限られたリソースを使っ てできるだけ多くのお客さんを満足させること. これは最適化問題そのものです.リソースとし て考慮すべきは車両数だけではありません，線 路容量, 乗務員のシフト, 駅施設の乗客処理能 力など，様々な制約条件を満たす解を瞬時に導 き出し，乱れたダイヤを収束させなければなり ません。これは当時も今も職人技の領域で, 熟 練したスジ屋の赤鉛筆に頼っています．鉛筆に 頼ると聞くと何とかその作業をシステムで自動 化したくなりますね.もちろん長年, 乱れたダ イヤの修正を自動化するシステムは研究されて
きました。ですが，本格的な実証実験が始まった のは, なんと 2021 年. 研究成果が実用化される のに十年単位の時間がかかる世界なのです。人 命を預かるソフトウェアに信頼性が求められる のは当然ですが，運行管理にバグがあっても列 車は衝突しない.下位レイヤーである信号保安 システムによって担保されているからなんです. この現場で，コンピュータシステムの構成要素 のうち最も柔らかいのはハードウェアで，最も 固いのはユーザである，という学びを得ました。 もっと柔らかい環境に身を置いて，研究成果 をすぐユーザに使ってもらえるような仕事がし たい. そう一念発起して，再び合田憲人研究室 の門を吒いたのが 2008 年のことです，当時普及 し始めたクラウドコンピューティングは，まだ エコシステムが確立したとは言えず，ユーザは ベストプラクティスを求めて右往左往していま した。複数の会社が似たようなサービスを提供 しているものの, 性能も価格体系もバラバラで 単純に比較できない。 そこで，クラウド資源の 先物市場のようなものがあったら良いのではな いかと思いました.「市場」という名前ですが, 実際はオークション会場のようなもので，そこ ヘプロバイダが自社サービスを「○時から○時 まで，ストレージ○ GB，1 時間につき○円以 上」といった形で出品する。ユーザは「○時か ら○時まで，ストレージ○ GB, CPU○コア，合 計○円以下」といった形で入札する。 ユーザが 希望する資源が入札価格以内で全部揃えばマッ チングが成立するという仕組みを提案しました。 組合せオークションという方法を用いて，複数 種類の資源に対し「全部揃えば買う。さもなけ れば何も買わない」という要求を可能としたの がポイントです。これを混合整数計画問題とし てモデル化し，シミュレーションで実現可能性 を示しました.コンピュータシステムの研究と いうより，どちらかというと厚生経済学の研究 
に近かったですね。論文を国際会議で発表した 2010 年当時, クラウド先物市場などというもの は需要も実例も存在せず, それこそ cloud を掴 むような苦しい研究生活だったのを覚えていま す。当時発表した論文は 2021 年 5 月現在， 110 件ほど引用されているようです。ようやく時代 が追いついてきた感じがします (笑).

2012 年からは国立情報学研究所・鯉㴊道紘研 究室でスーパーコンピュータのネットワークを 研究しました.スーパーコンピュータというと 1 個の巨大な計算機をイメージするかもしれま せんが，実際は何千何万台もの小さな計算機が ネットワークで互いに繋がってできています。た くさんの計算機でデータを分散処理して同期す るため, 計算機の台数が増えれば増えるほど, 全体の性能がネットワークに律速されてしまい ます。つまり，ネットワークを低遅延化するこ とが性能向上の鍵となります。一般的なネット ワーク設計では，計算機同士をツリー状や格子 状に繋ぎます。この規則性をなくして計算機同 士をランダムに繋ぐことによってネットワーク を劇的に低遅延化できることが鯉㴊先生の研究 によって明らかになりました。ところが，ラン ダムなネットワークを素直に実装すると, 配線 ケーブルがとんでもない長さになってしまいま す。そこで，計算機の配置を最適化したり，格 子状の配線のままネットワークをランダム化し たり，配線をなくして無線化したり，ランダム ネットワーク実現の障壁を下げる方法をいろい ろ研究しました。ただ残念ながら，現在に至る までランダムネットワークを採用したスーパー コンピュータは現れていないようです.

鯉㴊研で取り組んだもう一つのテーマが，水 没コンピュータです. 最近のチップマルチプロ セッサには多数の CPUが集積されていて，その 単位体積あたりの発熱量, 熱密度は電気コンロ 並みです，集積度が上がれば上がるほど，チッ
プ表面からの放熱が間に合わなくなります。現 状では，チップは金属製の水枕を介して冷却水 と熱交換し，その冷却水はチラー（循環液と呼 ばれる液体を循環させて機器の温度を調整する 装置）を介して外気と熱交換するのが一般的で す。この間接冷却方式は, 冷却システムを運転 するためにそれなりの電力を消費します，建屋 の給電能力が高性能計算機導入の制約条件とな る昨今，冷却のために余計な電力を使う余裕は ありません，そこで，CPUを含む基板全体を流 水に沈める直接冷却方式を思いつきました。

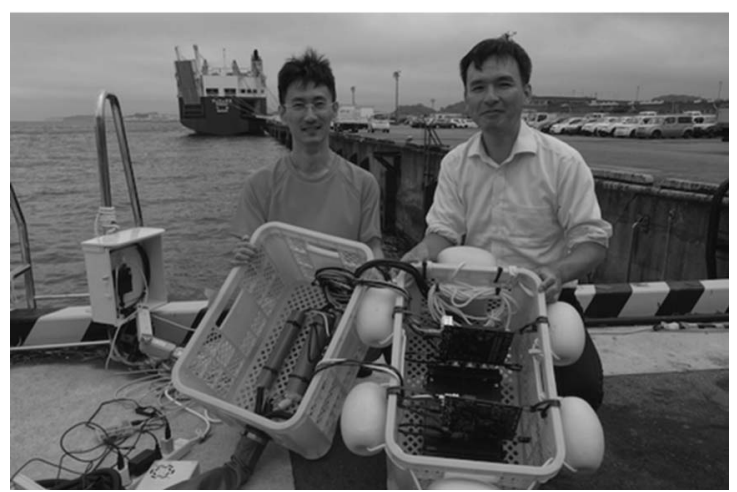

表面に薄いプラスチック膜をコーティングし たマザーボードを東京湾に沈めて実験したとこ ろ，53 日間，海中で動き続けました。空中だと ファンを用いても 80 度近くに達してしまう $\mathrm{CPU}$ も, 海中では 56 度くらいで安定動作しました。 技術面や法律面など課題も見えてきて実用化は 断念したのですが，可能性のあるアイデアだっ たと思います。例えば，水力発電所に水没コン ピュータを組み込めば，発電所で生まれた電気 をその場で計算パワーに変換し，熱は川に流し て，情報だけが運ばれていく軽量なクラウドコ ンピュータになりえます。現在は，民間企業と 連携して屋内向け水道水冷却の試作機を開発中 です.

その後, NICT（情報通信研究機構）を経て, 2018 年から現職に勤めています。論文だけ書い ていても理想の世界は実現しない. かといって 
エンジニアリングだけやっていても理想の世界 は遠いまま。企業とアカデミア，両極端な環境 を体験したからこそ，その二つが重なる領域で 挑戦することの面白さが今はとてもよく分かり ます。これまでの経験を糧に，今後はオープン サイエンスの潮流を広げていきたいです。

\section{一 研究会についてお聞かせ下さい.}

私が専門委員を務める CPSY（コンピュータシ ステム研究専門委員会) は, コンピュータ・アー キテクチャにまつわる研究を幅広く扱う，わり と何でもありな研究会です.コンピュータシス テムは，電気を食って熱を吐く論理回路に始ま り, 半導体に蝕刻された集積回路, 磁場を固定 する記憶装置, 光を届ける通信機器を経て自律 分散システムに至る，物理世界と論理世界の間 に広がる巨大な路線網のようなものだと思って います。それぞれの要素技術が駅だとすれば，関 連の深い要素技術を束ねたレイヤーが路線です。 路線ごとにそれぞれ専門の研究会が活動してい る中で，CPSYは既存の路線にとらわれず，駅 と駅を勝手に結んで新しい路線を作っちゃうよ うな，フリーダムな研究をすくい上げる役割を 果たしているのではないかと思います。フルス タック人材が熱量高くエキサイティングな研究 を持ち寄る CPSYにもっと御期待頂けると嬉し いです。

\section{— 最後に趣味についてお聞かせ下さい.}

キーボードの最適化がライフワークです.か れこれ 18 年にわたって, パソコンを快適に操 るためのキー配列を追求しています。 2004 年に は，スペースキーを押しながら文字キーを押す と Enter や Delete やカーソルなどの機能キーが 入力できる操作体系を確立しました. この手法 は自作キーボード界隈で「レイヤー」と呼ばれ,
最近ようやく市民権を得てきたようです，日本 語入力に関しては，有名な親指シフトに対抗し て，親指キーを用いない高効率な日本語入力方 式を開発しています，高効率とは，典型的な和文 を書くときにキーを打つ回数が少ないという意 味です．独自の分析 [1]によると，普通のローマ 字入力では 100 字書くのに 168 回キーを打つの に対して，私が開発した「ブリ中トロ配列」を用 いると 122 回で済みます.「ブリ中トロ配列」は, 打ちやすいホームポジションのキーを頻繁に使 い，打ちにくい周縁部のキーをあまり使わず，各 指の負担率が左右対称となるように設計しまし た.人間の手は左右対称なのに，キーボードの 形や指の負担が著しく非対称なのは合理的では ありませんよね. 最近は左右対称型の自作キー ボードキットも各種ありますし，皆さんも不合 理なお仕着せのキーボードを投げ捨てて，自分 の手に合った快適なキーボードを探求してみて はいかがでしょうか. とても深くて温かい沼で すよ.

最近ですが，息子が産まれました。当然デジ タルネイティブに育つのでしょうが，野山を駆 け回る原体験も重要だと思っています。先輩パ パママの御意見や体験談を是非聞きたいです.

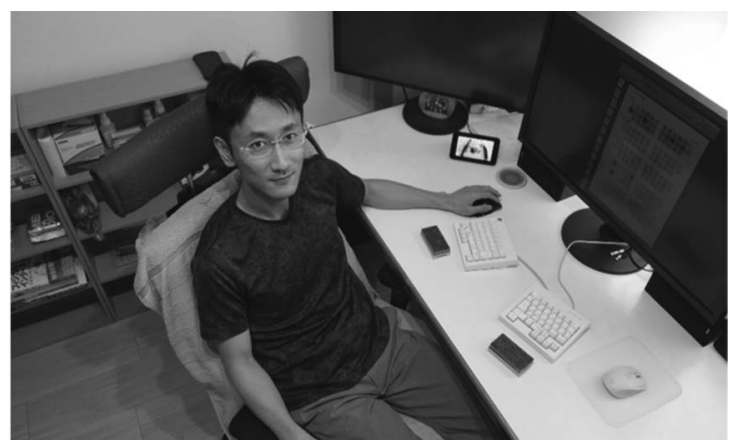

\section{参考文献}

[1] https://mobitan.hateblo.jp/entry/2021/01/26/ 192354 